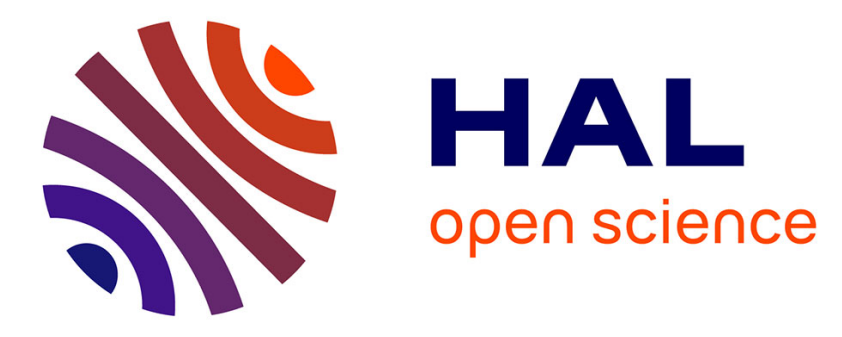

\title{
Multiscale and age-dependent leaf nickel in the Ni-hyperaccumulator Leptoplax emarginata
}

François Bartoli, Mathilde Royer, David Coinchelin, Didier Le Thiec, Christophe Rose, Christophe Robin, Guillaume Echevarria

\section{- To cite this version:}

François Bartoli, Mathilde Royer, David Coinchelin, Didier Le Thiec, Christophe Rose, et al.. Multiscale and age-dependent leaf nickel in the Ni-hyperaccumulator Leptoplax emarginata. Ecological Research, 2018, 33 (4), pp.723-736. 10.1007/s11284-018-1594-0 . hal-01854605

\section{HAL Id: hal-01854605 https://hal.science/hal-01854605}

Submitted on 26 May 2020

HAL is a multi-disciplinary open access archive for the deposit and dissemination of scientific research documents, whether they are published or not. The documents may come from teaching and research institutions in France or abroad, or from public or private research centers.
L'archive ouverte pluridisciplinaire HAL, est destinée au dépôt et à la diffusion de documents scientifiques de niveau recherche, publiés ou non, émanant des établissements d'enseignement et de recherche français ou étrangers, des laboratoires publics ou privés. 


\section{Multiscale and age-dependent leaf nickel in the Ni-hyperaccumulator Leptoplax emarginata}

Received: 2 October 2017 / Accepted: 6 January 2018

(C) The Ecological Society of Japan 2018

\begin{abstract}
Nickel-hyperaccumulator plants are of interest due to their potential use in agromining. We aimed to characterize leaf traits and $\mathrm{Ni}$ concentration variabilities occurring between individual plants, leaves of differing age or between various leaf tissues, in a single Greek population of the Ni-hyperaccumulator Leptoplax emarginata (Boiss.) O.E. Schulz. We linked these results to ecophysiological characteristics and other element concentrations at leaf and leaf tissue scales. We measured leaf gas exchanges, stomatal density, and we carried out rapid freezing and freeze-drying processes on leaf sections before microanalysis with scanning electron microscopy and energy-dispersive spectrometry. Leaf or leaf-tissue $\mathrm{Ni}$ concentrations were influenced by a combination of individual plant and leaf age factors. The greatest $\mathrm{Ni}$ concentrations were found in the highly transpiring young and thin leaves with the greatest stomatal densities. Indeed, Ni was statistically seven times more concentrated in both epidermis layers than in their bulk neighbour leaf counterparts, whatever the leaf age. In both epidermis layers, increases in the $\mathrm{Ni}-\mathrm{S}$ and $\mathrm{Mg}-\mathrm{S}$ correlations from the oldest leaves to the youngest ones were observed. The Mg:Ni, $\mathrm{Ca}: \mathrm{Ni}$ and $\mathrm{P}: \mathrm{Ni}$ mass
\end{abstract}

Electronic supplementary material The online version of this article (https://doi.org/10.1007/s11284-018-1594-0) contains supplemen tary material, which is available to authorized users.

Deceased: François Bartoli.

F. Bartoli · M. Royer · D. Coinchelin · G. Echevarria $(\bowtie)$ Laboratoire Sols et Environnement, Université de Lorraine, INRA, 54000 Nancy, France

E-mail: guillaume.echevarria@univ-lorraine.fr

C. Robin · M. Royer

Laboratoire Agronomie et Environnement, Université de Lorraine, INRA, 54000 Nancy, France

D. Le Thiec $\cdot$ C. Rose

INRA, Université de Lorraine, Ecologie et Ecophysiologie

Forestières, 54000 Nancy, France

D. Le Thiec

INRA, EFABA, 54000 Nancy, France ratios decreased from the oldest leaves to the mature leaves. We would recommend time-series characterization of leaf traits belonging to at least three plant replicates in order to take into account the allogamous character of many Ni-hyperaccumulator plants. Longdistance Ni transport via the xylem is predominant in the Ni-hyperaccumulator $L$. emarginata whereas a complementary redistribution via the phloem should also occur. The perspectives of this study are the validation and refinement of this process over shorter periods using relevant tracers.

Keywords Nickel hyperaccumulation - Age-dependent leaves · Age-dependent leaf-tissues - Allogamy ·

Transpiration

\section{Introduction}

Most metal-hypertolerant plants (e.g. Ernst et al. 2008) are non-accumulating excluders, limiting the root-toshoot metal translocation via the xylem (Baker and Brooks 1989). In contrast, a minority of plants growing on metalliferous soils accumulate metals in their leaves to such high levels (e.g. see reviews by Verbruggen et al. 2009 and Krämer 2010) that they are called hyperaccumulators (Brooks et al. 1977). These are plants of interest due to their potential use in the phytoremediation of toxic metals, such as cadmium (e.g. McGrath et al. 2002; Koopmans et al. 2007; Tang et al. 2012), or in the phytomining or agromining of precious metals such as nickel (Nick and Chambers 1995; Li et al. 2003, Robinson et al. 2003a; Chaney et al. 2007; Bani et al. 2015; van der Ent et al. 2015).

At the shoot, leaf and leaf-tissue scales, Ni detoxification in Ni-hyperaccumulator plants has mainly been attributed to (1) Ni complexation with carboxylate ligands (e.g. Montargès-Pelletier et al. 2008; McNear et al. 2010; van der Ent et al. 2017) and (2) Ni sequestration in both epidermis layers (walls and/or vacuoles) instead of the mesophylls (Krämer et al. 2000; Küpper 
et al. 2001; Robinson et al. 2003b; Kachenko et al. 2008a, 2008b). As for Ni-hyperaccumulators from the Brassicaceae family (Montargès-Pelletier et al. 2008), it was demonstrated that malate is responsible for Ni tolerance in the non-accumulator Arabidopsis thaliana (Agrawal et al. 2012) and in the phloem sap of the hyperaccumulator Noccaea caerulescens (Deng et al. 2016). In general, both citrate and malate seem to be involved in Ni chelation in the majority of Ni-hyperaccumulators (van der Ent et al. 2017). These detoxification mechanisms also occur for other metals (Küpper et al. 2004; Cosio et al. 2005; Freeman et al. 2006; Xu et al. 2006; Vogel-Mikus et al. 2008; Tian et al. 2009; Fernando et al. 2010). The preferential storage in the epidermis suggests that $\mathrm{Ni}$, as other metals, is transported along with the transpiration stream, as also indicated by its intense localization in the leaf marginal areas and edges, and in the leaf vascular bundles and veins (Mesjasz-Przybylowicz et al. 2001; Kachenko et al. 2008b; Mesjasz-Przybylowicz and Przybylowicz 2011). Also, phloem redistribution of $\mathrm{Ni}$ seems to be a common process in Ni hyperaccumulating Brassicaceae that explains why flowers and seeds are so rich in $\mathrm{Ni}$ (Estrade et al. 2015; Deng et al. 2016). These processes could also show a more complex behaviour of $\mathrm{Ni}$ in leaves, in which the sink might not be an irreversible one.

Huge leaf Ni concentration variabilities occur between individual plants in a single population of a considered Ni-hyperaccumulator plant (Nick and Chambers 1995; Boyd et al. 1999; Boyd and Jaffré 2009; Richau and Schat 2009) or between branches and leaves in an individual metal-hyperaccumulator plant (Boyd et al. 1999; Perronnet et al. 2003; Robinson et al. 2003b). However, leaf-tissue Ni analyses were often carried out on a single leaf and rarely on an age-dependent leaf series. Moreover, this leaf or these leaves were always sampled from a single individual hyperaccumulator plant. The leaf-age effect was studied for $11 \mathrm{New}$-caledonian woody Ni-hyperaccumulator species and no real variation in Ni concentration in leaves (Boyd and Jaffré 2009). Only on Geissois pruinosa and Homalium kanaliense - two hypernickelophore species (i.e. species that accumulate more than $1 \% \mathrm{Ni}$ in their aboveground biomass as defined by Jaffré and Schmid 1974) - there were significant variations, which did not seem to correlate with leaf age. The leaf trait approach for metal hyperaccumulators has been developed recently (Lange et al. 2017a, b). Following such approaches, they found that functional leaf traits such as the specific leaf area (SLA) seemed to exhibit a homeostatic response to Co. We therefore wanted to specifically investigate this aspect to better understand the impact of physiological leaf traits (transpiration and leaf growth) on Ni hyperaccumulation in leaves in a herbaceous semi-perennial hipernickelophore from the Brassicaceae family, Leptoplax emarginata.

Thus, the purpose of the present study was threefold: (1) to study the respective impact of individual plant replicates and leaf age on leaf or leaf-tissue Ni concen- tration for the Ni-hyperaccumulator L. emarginata cultivated on a fertilized and Ni-contaminated sandy topsoil; (2) to link leaf or leaf-tissue Ni concentration to leaf ecophysiological characteristics. We sought to validate the hypothesis that leaf or leaf-tissue Ni concentrations are highest in young leaves, where leaf biomasses are lowest and transpiration rates at their highest; and (3) to study, in the leaf tissues, the relationships between $\mathrm{Ni}$ concentration and concentrations of key nutriments $(\mathrm{Mg}, \mathrm{Ca}, \mathrm{P}, \mathrm{K})$, which are also relevant physiologic tracers.

\section{Materials and methods}

Plants, porous media and solutions

The hyperaccumulator plant selected was the Ni-hyperaccumulator Leptoplax emarginata (Boiss.) O.E. Schulz (Brassicaceae), endemic to serpentine soils in Greece (Reeves et al. 1980; Bani et al. 2009; Cecchi et al. 2010). Seeds of L. emarginata were sampled in July 2006 in the Trigona village, Pindus Mountains, Central Greece (830 m a.s.1.) (Bani et al. 2009). These were removed from their siliques before use. The mean $\mathrm{Ni}$ content of a single seed without its outer shell was $16.4 \mu \mathrm{g}$ per air-dried seed. The porous media were (1) a fertilized calibrated sedimentary sand (particle size distribution ranging from 0.4 to $0.8 \mathrm{~mm}$, Sibelco, France) from Hostun, South-Eastern France for the pre-cultures and (2) a fertilized and Ni-contaminated sandy topsoil from a cultivated podzol (Food and Agriculture Organization of the United Nations (FAO) 2001), SouthWestern France, for the cultures. More details are available in Coinchelin et al. (2012).

The porous media were both supplied with a nutritive solution containing $998 \mu \mathrm{M} \mathrm{Ca}\left(\mathrm{NO}_{3}\right)_{2}, 4 \mathrm{H}_{2} \mathrm{O} ; 823 \mu \mathrm{M}$

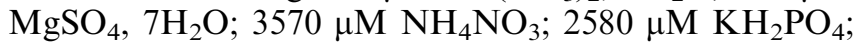
$71.6 \mu \mathrm{M} \mathrm{FeSO}, 7 \mathrm{H}_{2} \mathrm{O} ; 9.1 \mu \mathrm{M} \mathrm{MnSO}_{4}, \mathrm{H}_{2} \mathrm{O} ; 4.59 \mu \mathrm{M}$ $\mathrm{ZnSO}_{4}, \quad 7 \mathrm{H}_{2} \mathrm{O} ; \quad 9.25 \mu \mathrm{M} \quad \mathrm{H}_{3} \mathrm{BO}_{3}, \quad 4 \mathrm{H}_{2} \mathrm{O} ; 0.157 \mu \mathrm{M}$ $\mathrm{CuSO}_{4}, 5 \mathrm{H}_{2} \mathrm{O} ; 0.104 \mu \mathrm{M} \mathrm{Na} \mathrm{MoO}_{4}, 2 \mathrm{H}_{2} \mathrm{O}$. For the sandy topsoil, Ni contamination $\left(\mathrm{NiSO}_{4} 7 \mathrm{H}_{2} \mathrm{O}\right)$ in the initial fertilizing solution was $1700 \mu \mathrm{M}$ Ni but this initial $\mathrm{Ni}$ concentration greatly reduced to $10.3 \pm 0.4 \mu \mathrm{M}$ Ni (pH $6.44 \pm 0.02)$ after 1 week of soil solution ageing in the medium and just before plant transplantation (Coinchelin et al. 2012).

Each pot was lined with a polyethylene bag to prevent leakage and filled with $1.37 \mathrm{~kg}(1.51$ pot $)$ or $0.91 \mathrm{~kg}$ (1 1 pot) of sandy topsoil, and 1 week before the culture this was gently mixed with, respectively, 200 or $133 \mathrm{ml}$ of the fertilizing solution or the fertilizing and Ni-contaminated solution, in order to obtain a volumetric porous medium solution of $0.2 \mathrm{~cm}^{3} \mathrm{~cm}^{-3}$. A white polyethylene film covered the top of each pot, with a single $1-\mathrm{cm}$ diameter hole for all the planted and unplanted pots. 

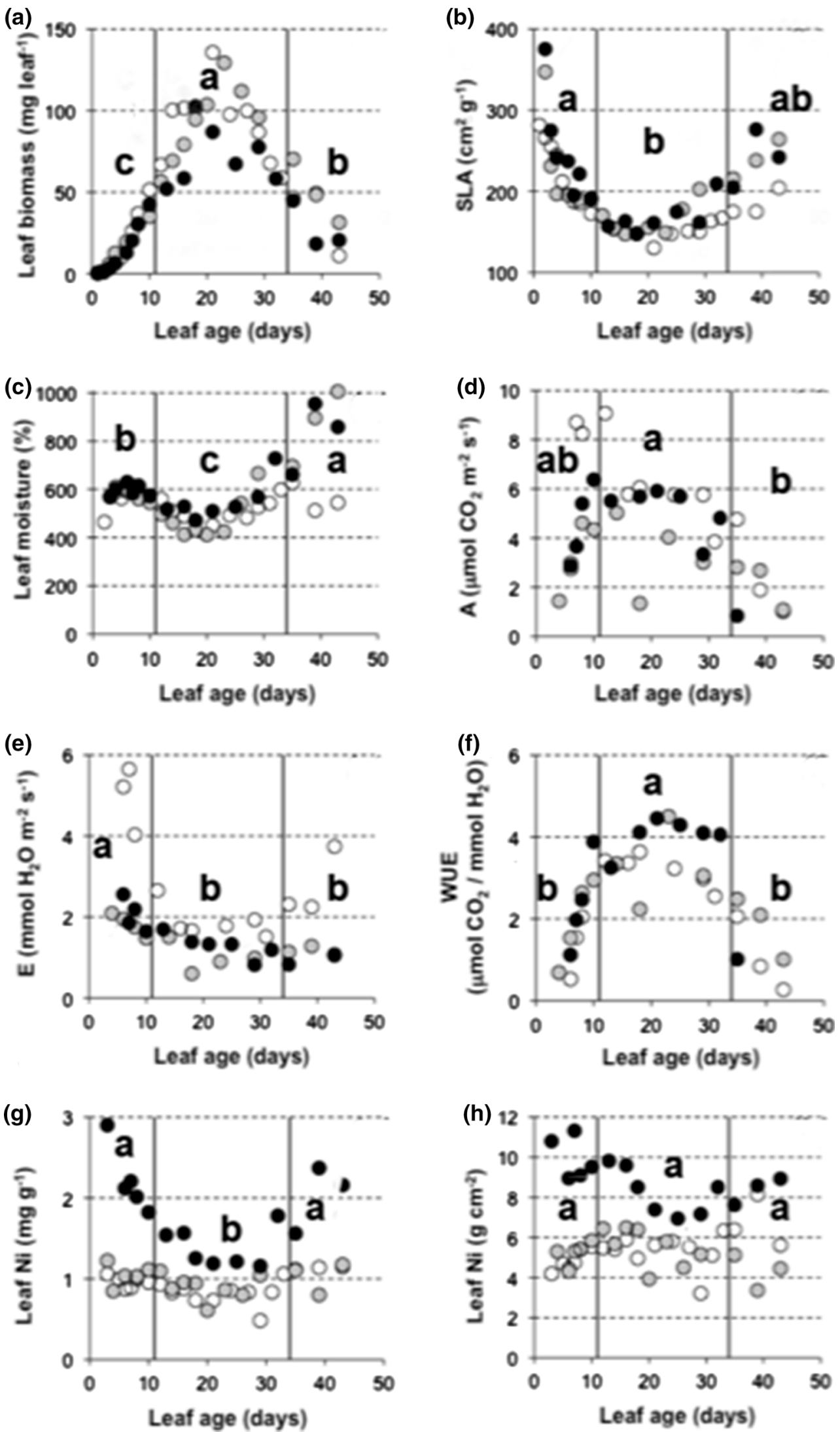
4 Fig. 1 Age-dependent distributions of dry-weight leaf biomass (a), specific leaf area, SLA (b), leaf moisture normalized to the dryweight leaf biomass (c), net $\mathrm{CO}_{2}$ assimilation, $\mathrm{A}$ (d), leaf transpiration flux, $E(\mathbf{e})$, water use efficiency (WUE $=\mathrm{A}: \mathrm{E}$ ratio) (f), leaf $\mathrm{Ni}$ concentration (g) and leaf Ni concentration normalized to the leaf area (h) for the P1 (open circles), P2 (grey circles) and P3 (closed circles) plant replicates cultivated on the fertilized and $\mathrm{Ni}$ contaminated sandy topsoil for 43 days. The old leaves (35-43 dayold), the mature leaves (12-33 day-old) and the young leaves ( $<11$ day-old) were differentiated using vertical line separations, leaf age being referred to the starting time of the culture. For each ecophysiological characteristic and leaf $\mathrm{Ni}$ concentrations, the statistically different leaf groups according to both leaf age range and plant replicate, were marked by different letters (two-way ANOVA and Tukey's HSD test with $\alpha=0.05$ and $P<0.05$ )

Plant growth, gas exchanges and plant samplings

Leptoplax emarginata seeds were germinated in the fertilized sand for a 2-week pre-culture, except for the cultures for 35 days in 11 pots (pre-culture of 5 weeks). The growing conditions were as follows: a 16-h photoperiod, with a photon flux density of $325 \mu \mathrm{mol}$ photons $\mathrm{m}^{-2} \mathrm{~s}^{-1}$ in the Parabolic Anodized Reflector (PAR) range, $20^{\circ} \mathrm{C}$ day $/ 18^{\circ} \mathrm{C}$ night temperatures and $50 \%$ relative humidity. The daily vapour pressure deficit was $1.17 \mathrm{kPa}$.

For the 11 pots, the culture time was 35 days both for those plant replicates cultivated in the reference fertilized sandy topsoil, and those in the fertilized and Ni-contaminated sandy topsoil (two plant replicates per treatment). For the 1.51 pots, the culture time was 43 days (P1, P2 and P3 plant replicates) or 51 days (P4, P5 and P6 plant replicates) for the plants cultivated in the fertilized and Ni-contaminated sandy topsoil (three plant replicates per culture age: Fig. S1). The leaf age referred to was always the starting time of each culture (30 March 2009), all the dated leaves being developed thereafter. We established the relationship between leaf position and age, in order to sample one of the few very old (51 day-old) leaves, which appeared before Ni contamination, and representative leaves which appeared after Ni contamination: the old (43 day-old), mature (26 day-old) and young (16 day-old) leaves. These sampled leaves were used for scanning electron microscopy (SEM) and energy-dispersive spectrometry (EDS) analyses. For this, the leaves which appeared on April 1, 7, 13, 24 April and May 42009 were well-identified, with complementary observations on the leaf development throughout the culture.

The plants were irrigated daily with deionized water, to maintain the volumetric porous medium solution of $0.2 \mathrm{~cm}^{3} \mathrm{~cm}^{-3}$ constant throughout the culture, whilst assuming a sufficient soil buffer power favoring a constant $\mathrm{Ni}$ concentration in the solution.

The day before each sampling period, leaf gas exchanges were recorded on $55 \%$ of the leaves of the three plant replicates cultivated for 43 days (50, 55 and $60 \%$ for the P1, P2 and P3 plant replicates, respectively) and on $44 \%$ of the three plant replicates cultivated for
51 days $(47,38$ and $47 \%$ for the P4, P5 and P6 plant replicates, respectively), using a CIRAS-1 portable photosynthesis system (PP SYSTEMS Inc., USA). The photon flux density and temperature inside the leaf chamber delivered to the leaf area measured were normalized using a lamp (at $260 \mu \mathrm{mol}$ photons $\mathrm{m}^{-2} \mathrm{~s}^{-1}$ and temperature of $24.3^{\circ} \mathrm{C}$ ).

\section{Plant biomass and leaf traits}

Roots were collected and washed with deionized water in order to remove all the root-adhering particles. Leaf moisture, stem biomass, root biomass, as well as total and individual leaf biomass (LB) were determined after oven-drying at $70{ }^{\circ} \mathrm{C}$ till attaining a constant weight. The total and individual leaf area (LA) were determined using the WinFOLIA ${ }^{\circledR}$ Software, the total or individual specific leaf area (SLA = LA to LB ratio) being calculated thereafter. These parameters were systematically determined on the three plant replicates cultivated for 43 days, but not on the other plant replicates. Each oven-dried single leaf of the three plant replicates cultivated for 43 days and each of the leaves neighbouring those sampled for the SEM-EDS analyses was carefully crushed using an agate mortar to a $0.5 \mathrm{~g}$ aliquot. They were then dissolved and mineralized by a $\mathrm{HNO}_{3}: \mathrm{H}_{2} \mathrm{O}_{2}$ solution $(1: 1 \mathrm{v} / \mathrm{v})$ in open small reactors. The mixture was then heated in a microwave oven (Mars 5, CEM Corporation Inc., USA). The Ni contents in resulting solutions were determined by inductively coupled plasma optical emission spectrometry (ICP-OES, Liberty RL, Varian, Inc., USA).

Age-dependent SEM-image analyses of stomatal density

Twelve leaf discs of $1 \mathrm{~cm}^{2}$ were harvested on the very old (51 day-old), old (43 day-old), mature (26 day-old) and young (16 day-old) leaves to record stomatal density. They were immediately frozen in liquid nitrogen (van der Ent et al. 2017) and stored at $-80^{\circ} \mathrm{C}$ thereafter. Because leaves are amphistomatous, each disc was split for the separate analysis of the leaf's adaxial and abaxial sides. Sample discs were then stuck to aluminium stubs on a Peltier stage $\left(-50^{\circ} \mathrm{C}\right)$, before being examined under a controlled-pressure scanning electron microscope (model 1450VP, Leo, Cambridge, UK; $40 \mathrm{~Pa}$ inside the chamber, accelerating voltage $15 \mathrm{kV}$, working distance $8 \mathrm{~mm}$ ). Nine microphotographs at $\times 300$ were then taken of each sub-disc (upper or lower epidermis) and the number of stomata were counted.

Age-dependent leaf-tissue SEM-EDS microanalyses on freeze-dried leaf sections

Absolute concentrations of $\mathrm{Ni}$ and other elements cannot be measured directly using energy-dispersive spec- 
(a)

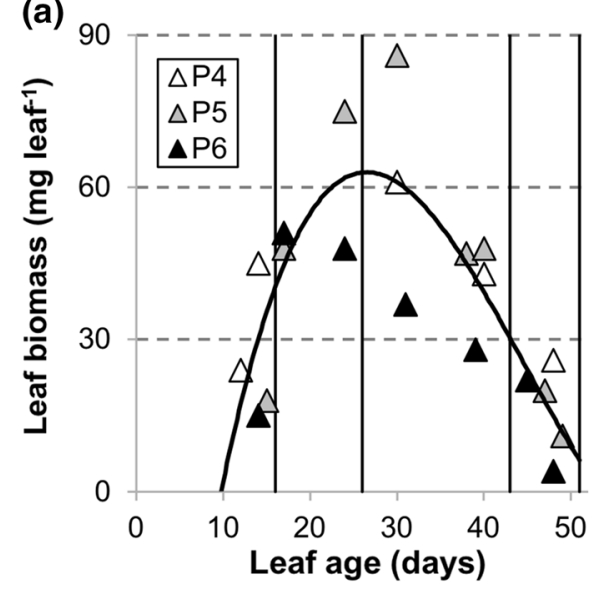

(c)
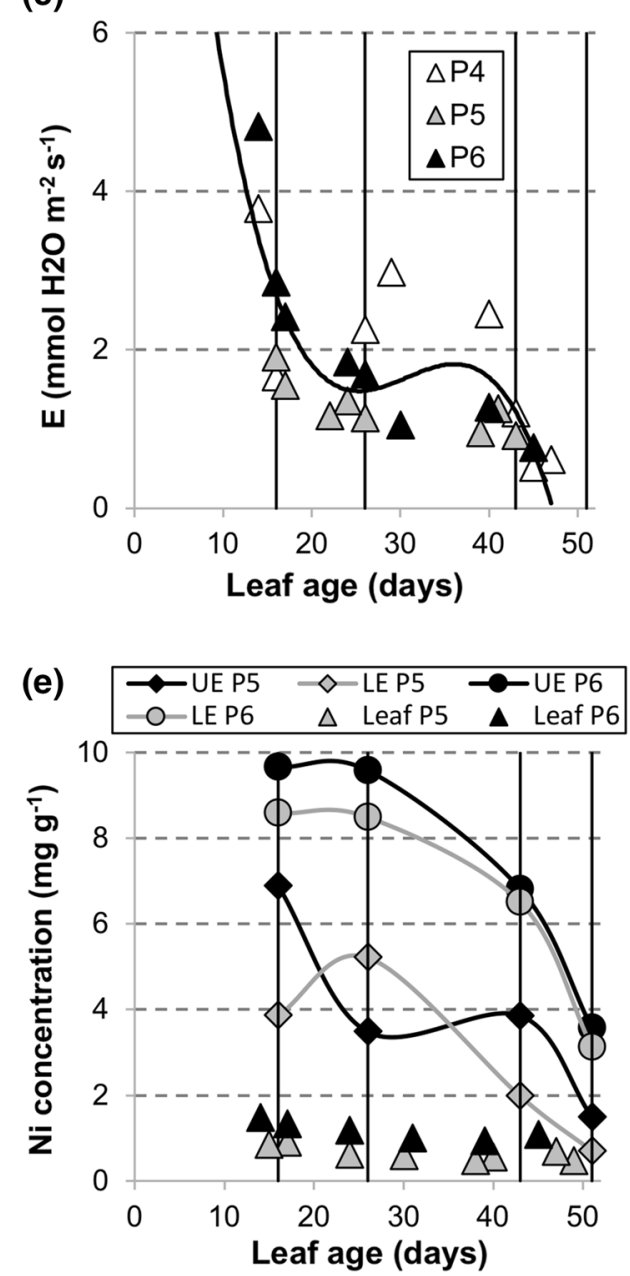

Fig. 2 Age-dependent distributions of dry-weight leaf biomass (a), water use efficiency (WUE = A:E ratio) (b), leaf transpiration flux, $E(\mathbf{c})$, mean stomatal density $(n=18: 3$ plant replicates and 6 stomatal density analysis per epidermis type, leaf age and plant replicate) in upper epidermis (UE) and lower epidermis (LE) (d), $\mathrm{Ni}$ concentration in leaf, upper epidermis (UE) and lower epidermis (LE) (e) for the plant replicates cultivated on the fertilized and Ni-contaminated sandy topsoil for 51 days. The four vertical line separations indicate the leaf age position of the very old (51 day-old), old (43 day-old), mature (26 day-old) and young

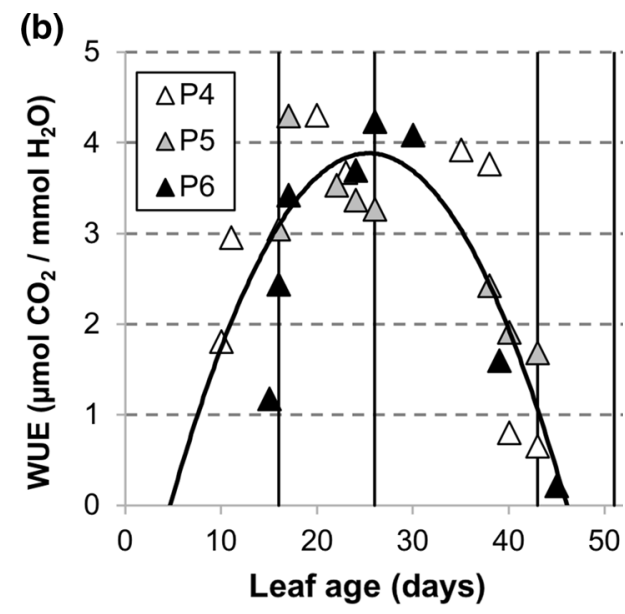

(d)
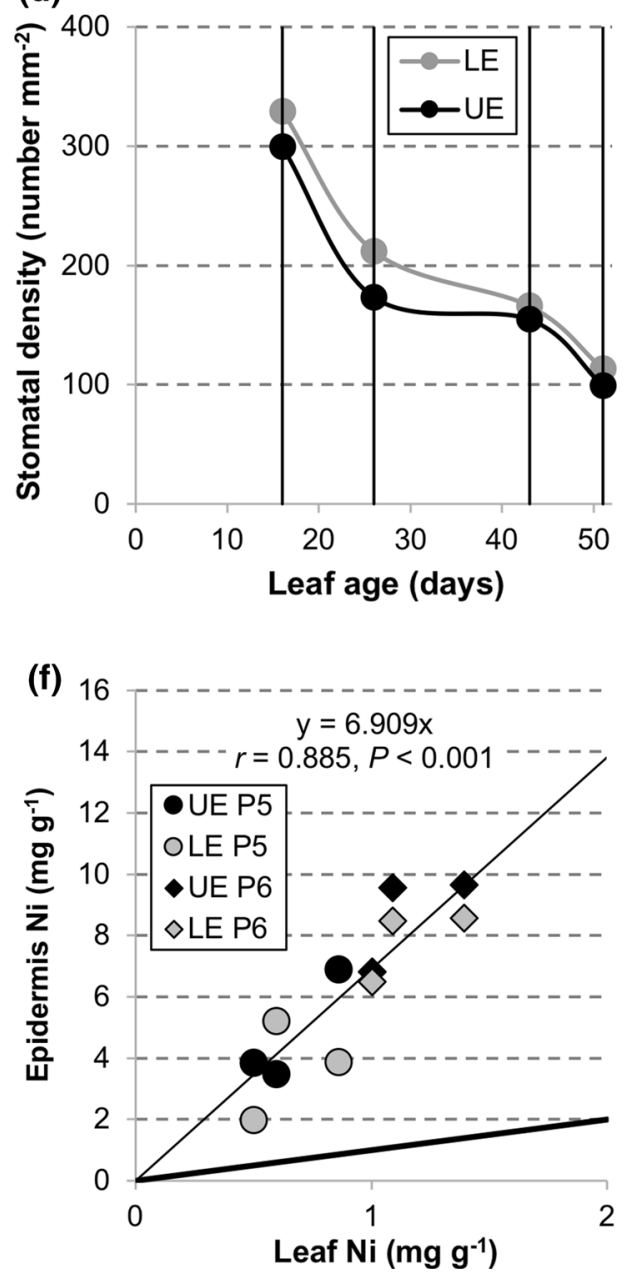

(16 day-old) leaves sampled in the three plant replicates for stomatal density measurements and scanning electron microscopy-energy-dispersive spectrometry (SEM-EDS) analyses. Leaf age was referred as that at the starting time of the culture. Corresponding linear relationship between mean Ni concentration in each epidermis $(n=27: 3$ plant replicates and 9 SEM-EDS analysis per leaf tissue, leaf age and plant replicate; Table S3) and mean $\mathrm{Ni}$ concentration in the neighbouring leaves $(n=2)$, the thick line being the bissectrix (f). At the leaf scale, open, grey and closed triangles $=\mathrm{P} 4, \mathrm{P} 5$ and $\mathrm{P} 6$ plant replicates 

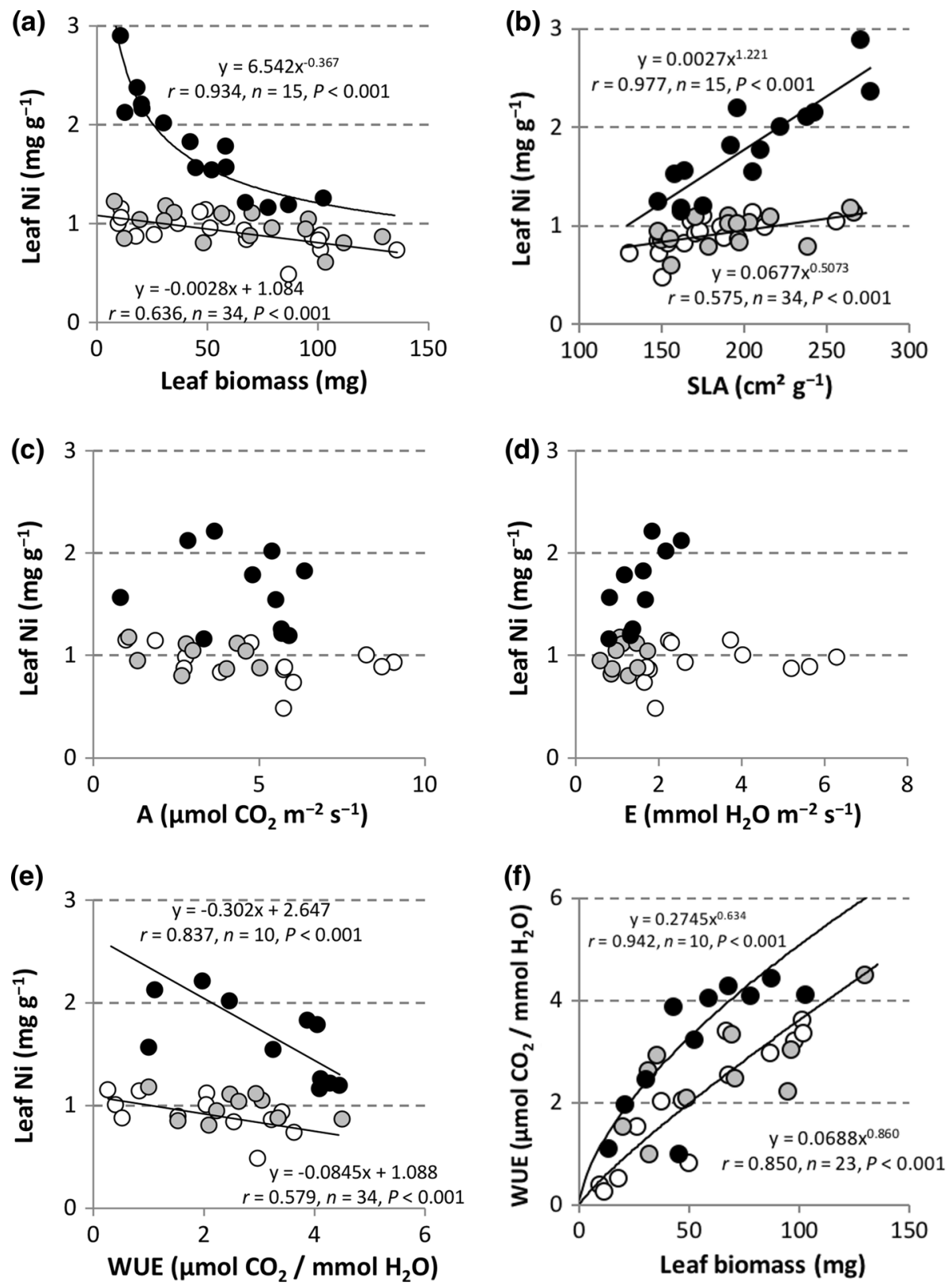

Fig. 3 Relationships between leaf Ni concentration and each of the following ecophysiological parameters: dry-weight leaf biomass (a), specific leaf area, SLA (b), net $\mathrm{CO}_{2}$ assimilation, $A$ (c), leaf transpiration flux, $E(\mathbf{d})$, and water use efficiency (WUE $=A: E$ ra-

tio) (e) for the P1 (open circles), P2 (grey circles) and P3 (closed circles) plant replicates cultivated on the fertilized and $\mathrm{Ni}$ contaminated sandy topsoil for 43 days. Corresponding relationships between WUE and leaf biomass (f)

trometry (EDS) on fully hydrated, fractured surfaces. In addition, the careful preparation of external standards is required, using the typical cocktail of elements likely to be found in the growing fresh leaf. Moreover, to acquire the most meaningful data from EDS systems, specimens should ideally be flat, polished and homogeneous. It follows that fractured, frozen or freeze-dried biological specimens are unable to meet these criteria. However, reasonable measures in instrument set-up and careful specimen preparation can go some way to satisfying the

first two requirements. The material to be analysed was prepared according to the method used in Le Thiec et al. (1994). Sections of plant material were examined under a scanning electron microscope (model 1450VP, Leo, Cambridge, UK) at $15 \mathrm{kV}$, equipped with a dispersive energy microanalysis system (EDX, diode $\mathrm{Si}-\mathrm{Li}$; the INCA Energy 300 software, Oxford Instruments). The Point and Identify Module was used to target cell types across the freeze-dried surface. The spectra acquired are semi-quantitative results based on calculations using the 

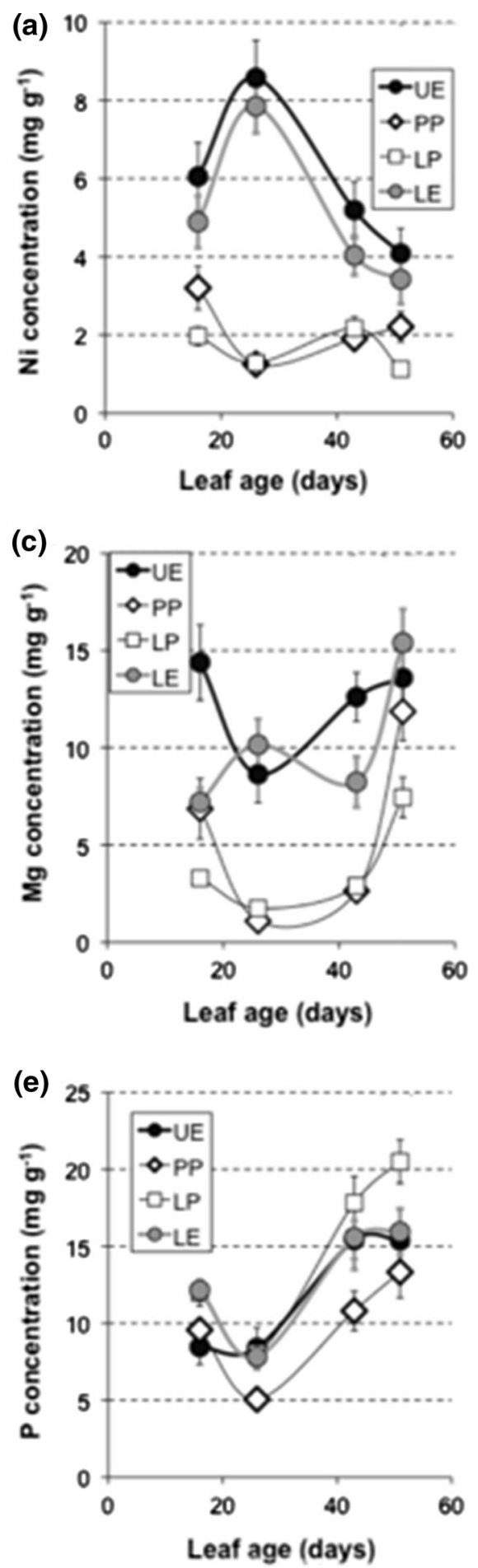

Fig. 4 Age-dependent tissue Ni concentration (a), S concentration (b), $\mathrm{Mg}$ concentration (c), Ca concentration (d), $\mathrm{P}$ concentration (e) and $\mathrm{K}$ concentration (f) in upper epidermis (UE closed circles), palissadic parenchyma (PP, open lozenges), lacunar parenchyma (LP, open squares) and lower epidermis (LE, grey circles) of the very old (51 day-old), old (43 day-old), mature (26 day-old) and young (16 day-old) leaves belonging to the three plant replicates

system's internal standards for each element and can be used to compare relative concentrations. The upper epidermis, palissadic parenchyma, lacunar (spongy)
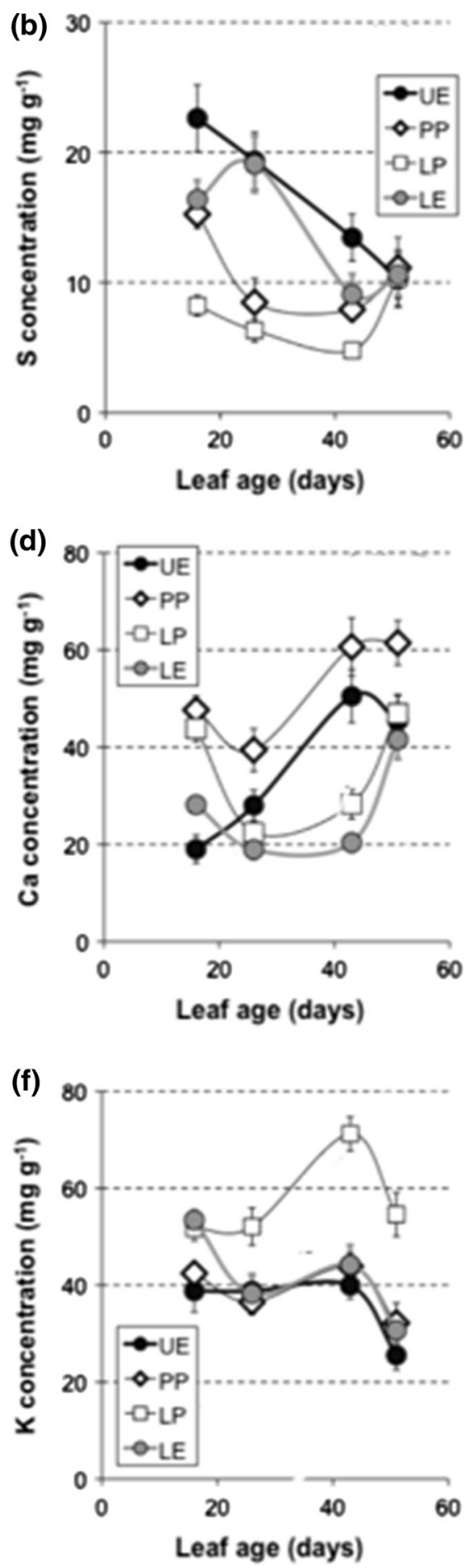

cultivated on the fertilized and Ni-contaminated sandy topsoil for 51 days (scanning electron microscopy-energy-dispersive spectrometry (SEM-EDS) analysis). Error bars show standard errors of mean values $(n=27: 3$ plant replicates and 9 SEM-EDS analysis per leaf tissue, leaf age and plant replicate; Table S3). Leaf age was referred to as that at the starting time of the culture

parenchyma and lower epidermis were analysed in the different-aged leaves. Nine analysis replicates per tissue were carried out. 

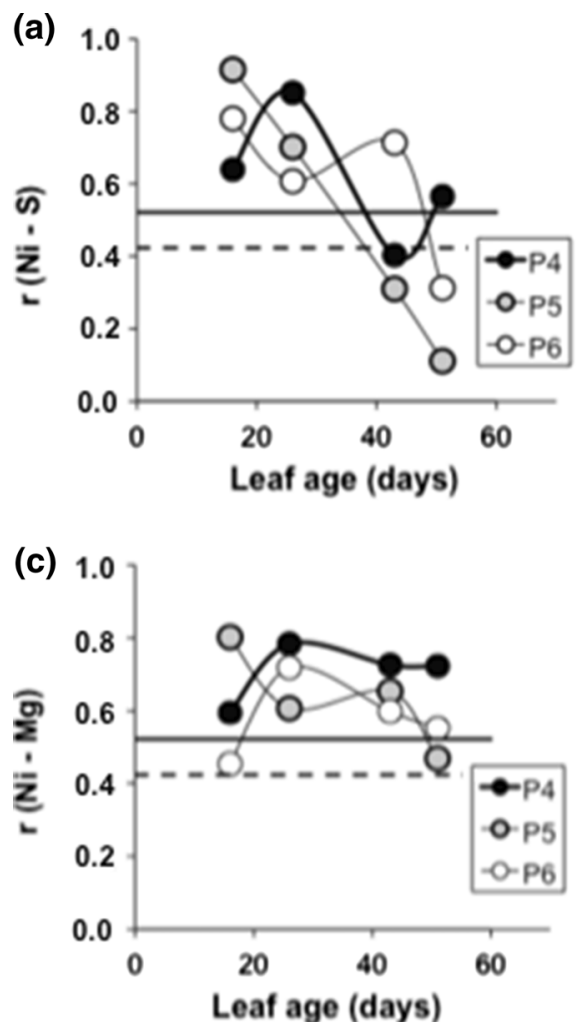

Fig. 5 Age-dependent $\mathrm{Ni}-\mathrm{S}(\mathbf{a}), \mathrm{Mg}-\mathrm{S}(\mathbf{b}), \mathrm{Ni}-\mathrm{Mg}$ (c) and $\mathrm{Ni}-\mathrm{Ca}$ (d) spatial correlation coefficients for the whole tissue series of the very old (51 day-old), old (43 day-old), mature (26 day-old) and young (16 day-old) leaves belonging to the P4 (closed circles), P5 (grey circles) and P6 (open circles) plant replicates cultivated on the fertilized and Ni-contaminated sandy topsoil for 51 days $(n=36$ :

Treatment- and leaf age-dependent SEM-EDS-WDS microanalyses of ground leaf pellets

Ground leaf pellets were put on an aluminium stub and coated with carbon. We used the energy-dispersive spectrometry (EDS) system for sulfur, magnesium, calcium, potassium and phosphorus; for $\mathrm{Ni}$ we used the wavelength-dispersive spectrometry (WDS) system with a pure metallic Ni as reference. Both EDS and WDS were linked to the same scanning electron microscope. The analyses were performed at $20 \mathrm{kV}$, sample current $50 \mathrm{nA}$, time $30 \mathrm{~s}$. Six analyses replicates per leaf pellet were carried out.

\section{Statistical analyses}

Statistical analyses and curve-fitting were carried out using the XLSTAT 2010 Excel package software or the KaleidaGraph ${ }^{\text {TM }} 3.52$ software package. Principal component analysis (PCA) and Spearman correlation matrices (because some $\mathrm{Ni}$ or nutrient concentration distributions were non-normal) were carried out using the XLSTAT 2010 Excel software package. The respective effect of individual plant and leaf age, and
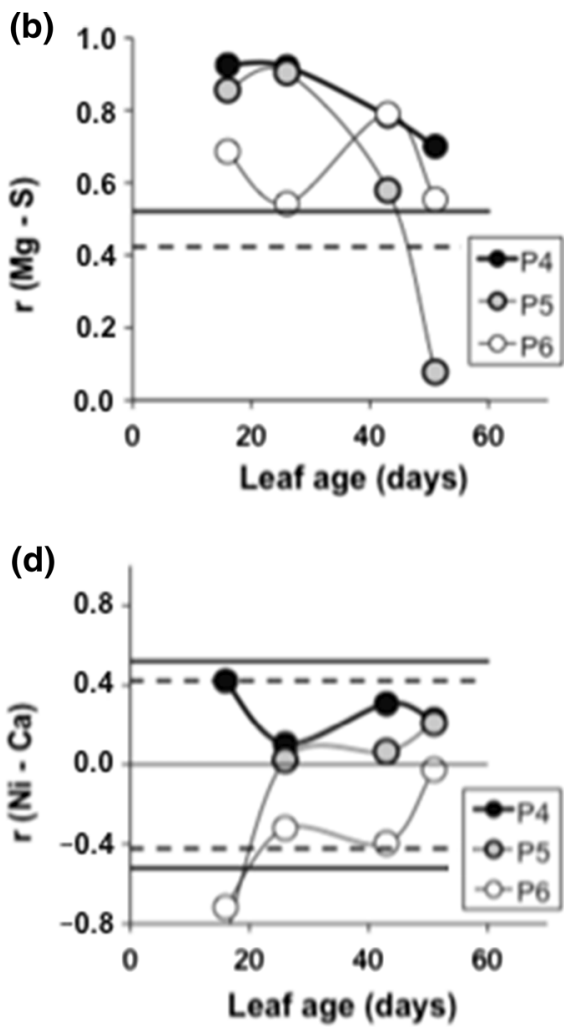

4 tissues per leaf and 9 scanning electron microscopy-energydispersive spectrometry (SEM-EDS) analysis replicates per leaf tissue, leaf age and plant replicate; Tables S4, S5 and S6). Leaf age was referred to as that at the starting time of the culture. The dashed line $(P<0.05)$ and the bold line $(P<0.001)$ represent the significance level of the correlation

their interaction (type III two-way ANOVA analysis) on the studied parameters were tested by performing a twoway ANOVA analysis (and the Tukey's HSD post hoc test with $\alpha=0.05$ and $P<0.05$ ), using also the XLSTAT 2010 Excel software package.

\section{Results}

Age-dependent ecophysiological leaf traits

At 43 days after plantation on the fertilized and $\mathrm{Ni}$ contaminated topsoil $\left(\mathrm{Ni}^{+}\right.$topsoil), the leaf biomass $(1142 \pm 92 \mathrm{mg})$ represented $82 \pm 2 \%$ of the shoot biomass, whereas the mean root/shoot ratio was of $0.15 \pm 0.02$ (data not shown). Three categories of leaves have been differentiated: the old (35-43 days-old), the mature (12-33 days-old) and the young leaves ( $<11$ days-old). The last category was characterized by a mean phyllochrone index of 1.25 , significantly greater than the other two phyllochrone indexes of 2.5 (Fig. S2). Leaf biomass was significantly greater for the mature leaves than for the old and young leaves (Fig. 1a), with only a leaf age effect. Both SLA and leaf moisture normalized to the dry leaf biomass were significantly greater 

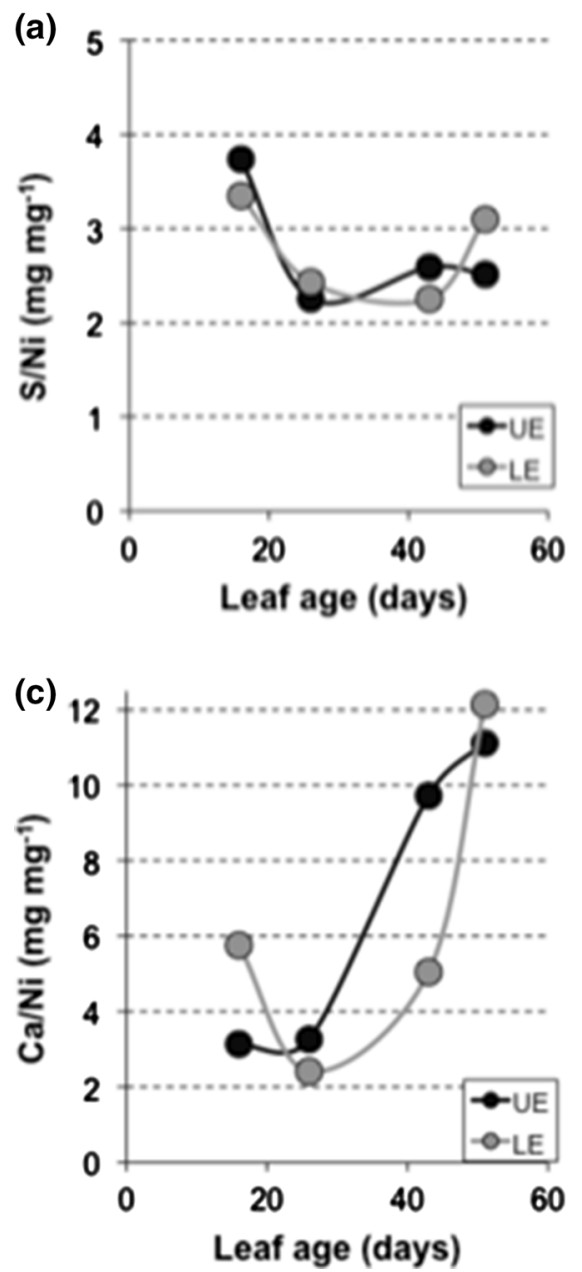

Fig. 6 Age-dependent $\mathrm{S} / \mathrm{Ni}$ mass ratio (a), $\mathrm{Mg} / \mathrm{Ni}$ mass ratio (b), $\mathrm{Ca} / \mathrm{Ni}$ mass ratio (c) and $\mathrm{P} / \mathrm{Ni}$ mass ratio (d) for the upper epidermis (UE closed circles) and the lower epidermis (LE, grey circles) of the very old (51 day-old), old (43 day-old), mature (26 day-old) and young (16 day-old) leaves belonging to the three

for the young leaves than for the mature leaves (Fig. 1b, c).

The transpiration flux (E) of mature leaves of the Nihyperaccumulator was similar, whatever the treatment. Net $\mathrm{CO}_{2}$ assimilation flux (A) and, therefore, the water use efficiency (WUE, computed as the quotient of Net $\mathrm{CO}_{2}$ assimilation flux [A]/cumulated volume of transpired water flux [E]), were significantly greater for the plants cultivated in the $\mathrm{Ni}+$ topsoil than for those cultivated in the reference fertilized topsoil without Nicontamination (Ni-topsoil) (Table S1). The age-dependent distribution of net $\mathrm{CO}_{2}$ assimilation flux was similar to that of leaf biomass at 43 days after plantation on the $\mathrm{Ni}+$ topsoil. However, this peaked at a lower leaf age value (Fig. 1a, d). The leaf transpiration flux was significantly greater for the young leaves than for the mature and old leaves (Fig. 1e), with a combination of leaf age and individual plant effects (two-way ANOVA analysis). Water use efficiency was significantly greater
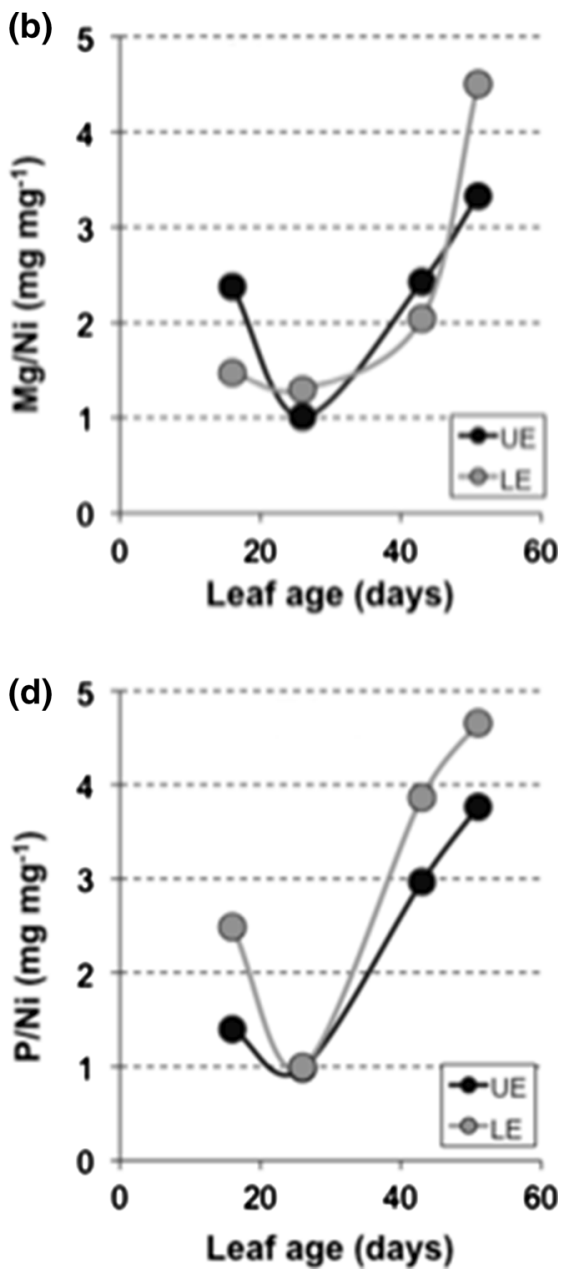

plant replicates cultivated on the fertilized and Ni-contaminated sandy topsoil for 51 days $(n=27$ : 3 plant replicates and 9 scanning electron microscopy-energy-dispersive spectrometry (SEM-EDS) analysis replicates by epidermis type, Table S3). Leaf age was referred as that at to the starting time of the culture for the mature leaves than for the young and old leaves (Fig. 1f), with a combination of leaf age and individual plant effects. The order of magnitude and age-dependent trends of gas exchange characteristics were similar for the leaves of both the 43-day-old plant replicates and the 51-day-old plant replicates (Figs. 1, 2). The leaf transpiration flux was always significantly greater for the young leaves $(\mathrm{E}=3.19 \pm 0.67$ or $2.71 \pm 0.46 \mathrm{mmol}$ $\mathrm{H}_{2} \mathrm{O} \mathrm{m} \mathrm{m}^{-2} \mathrm{~s}^{-1}$ for the 43 day-old or 51 day-old plant replicates, respectively) than for the mature leaves $\left(\mathrm{E}=1.43 \pm 0.14\right.$ or $1.59 \pm 0.17 \mathrm{mmol} \mathrm{H}_{2} \mathrm{O} \mathrm{m} \mathrm{m}^{-2} \mathrm{~s}^{-1}$ for the 43 day-old or 51 day-old plant replicates, respectively), with combined leaf age and individual plant effects. The age-dependent distribution of leaf transpiration flux was significantly $(P<0.001)$ fitted by a downward bell curve for the 43 day-old plant replicates (Fig. 1e), whereas it was significantly $(P<0.001)$ fitted by a sigmoidal curve for the 51 day-old plant replicates (Fig. 2c). As a complement, the transpiration 
flux of the old leaves was significantly lower for the 51 day-old plant replicates than for the 43 day-old plant replicates (Figs. 1, 2).

Stomata (Fig. S3) occurred on both sides of the leaf epidermis (Fig. S4). A positive stomatal density gradient occurred from the oldest leaves to the youngest ones, with a significantly greater stomatal density for the young leaves than for the other leaves whatever the plant replicate (Fig. S4; Fig. 2d). Stomatal density was similar for the upper epidermis and the lower epidermis and an individual plant effect on stomatal density was only identified for the mature leaves. Age-dependent distributions of both stomatal density (Fig. 2d) and leaf transpiration flux (Fig. 2c) were fitted by similar sigmoidal curves.

\section{Age-dependent leaf $\mathrm{Ni}$ and nutrient concentrations}

The same treatment- and leaf age-dependent trends occurred between the leaf $\mathrm{Ni}$ contents determined by SEM-WDS analysis on ground leaf pellets leaves and those determined by ICP-OES after mineralization of the same leaves (Table S2). However, for those plants cultivated in the fertilized and Ni-contaminated topsoil, the leaf $\mathrm{Ni}$ contents determined by SEM-WDS analysis were overestimated. Leaf $\mathrm{Ca}$ or $\mathrm{Mg}$ contents were constant, whatever the leaf age or the treatment, except for the old leaves, which were poorer in $\mathrm{Mg}$ when the fertilizing solution was contaminated with Ni (Table S2). Consequently, the mean $\mathrm{Ca}: \mathrm{Mg}$ mass ratios of 7.8-9.8 were similar. The young leaves were significantly richer in $\mathrm{S}$ than the old leaves, whatever the treatment, whereas they were richer in $\mathrm{Ni}$ and poorer in $\mathrm{P}$ when the fertilizing solution was contaminated with $\mathrm{Ni}$ (Table S2). The variabilities of leaf $\mathrm{Ni}, \mathrm{S}$ and $\mathrm{P}$ concentrations were explained by a combination of leaf age and treatment effects. The mean $\mathrm{Ca}: \mathrm{Ni}, \mathrm{K}: \mathrm{Ni}$ and $\mathrm{P}: \mathrm{Ni}$ mass ratios were significantly greater for the old leaves (mean $\mathrm{Ca}: \mathrm{Ni}$, $\mathrm{K}: \mathrm{Ni}$ and $\mathrm{P}: \mathrm{Ni}$ mass ratios of $11.4,19.3$ and 4.3, respectively) than for the young leaves (mean $\mathrm{Ca}: \mathrm{Ni}$, $\mathrm{K}: \mathrm{Ni}$ and $\mathrm{P}: \mathrm{Ni}$ mass ratios of $9.2,9.5$ and 1.6, respectively).

At 43 days after plantation on the $\mathrm{Ni}^{+}$topsoil, leaf $\mathrm{Ni}$ concentration was significantly lower for the mature leaves than for the young and old leaves (Fig. 1g), with combined leaf age and individual plant effects. Leaf $\mathrm{Ni}$ concentrations normalized to leaf area were statistically similar (Fig. 1h). Leaf $\mathrm{Ni}$ concentration decreased sharply as a function of leaf biomass for one plant replicate, whereas it slightly decreased as a function of leaf biomass for the other two plant replicates (Fig. 3a). Moreover, the slope of the linear relationship between leaf $\mathrm{Ni}$ concentration and SLA was high for one plant replicate but low for the other two plant replicates (Fig. 3b). No relationships were visible between leaf $\mathrm{Ni}$ concentration and either net $\mathrm{CO}_{2}$ assimilation flux or leaf transpiration flux (Fig. 3c, d), except for one plant replicate. Significant relationships occurred between leaf
$\mathrm{Ni}$ concentration and water use efficiency (WUE) (Fig. 3e). These later relationships were explained by both the negative non-linear relationships occurring between leaf Ni concentration and leaf biomass (Fig. 3a) and the positive non-linear relationships occurring between WUE and leaf biomass (Fig. 3f).

Thus, the ecophysiological characteristics, order of magnitude and age-dependent trends of leaf $\mathrm{Ni}$ concentrations were similar for the leaves of both the 43 day-old plants and the 51 day-old plants (Fig. 1g, e). Leaf $\mathrm{Ni}$ concentration was always significantly greater for the young leaves (leaf $\mathrm{Ni}$ concentration of $1.38 \pm 0.16$ or $1.25 \pm 0.13 \mathrm{mg} \mathrm{Ni} \mathrm{g}^{-1}$ for the 43 or 51 day-old plant replicates, respectively), than for the mature leaves (leaf $\mathrm{Ni}$ concentration of $1.00 \pm 0.06$ or $0.89 \pm 0.12 \mathrm{mg} \mathrm{Ni} \mathrm{g}^{-1}$ for the 43 day-old or 51 day-old plant replicates, respectively), with combined leaf age and individual plant effects. The age-dependent distribution of leaf $\mathrm{Ni}$ concentration was significantly $(P<0.01)$ fitted by a downward bell curve for the 43 day-old plant replicates (Fig. $1 \mathrm{~g}$ ), whereas it was significantly $(P<0.001)$ fitted by a power law curve for the 51 day-old plant replicates (Fig. 2e). Ni concentration of the old leaves was significantly lower for the 51 day-old plant replicates than for the 43 day-old plant replicates.

Age-dependent leaf-tissue nickel and nutrient concentrations

Nickel, $\mathrm{S}$ and $\mathrm{Mg}$ were mostly located in both layers (Fig. 4; Figs. S5 and S6; Table S3). In particular, Ni was statistically seven times more concentrated in the two epidermis than in their bulk neighbour leaf counterparts whatever the leaf age or the individual plant (Fig. 2e, f). This leads to significant positive spatial correlations between $\mathrm{Ni}, \mathrm{S}$ and $\mathrm{Mg}$ concentrations, whatever the leaf age or the individual plant, with only very few exceptions for the oldest leaves (Fig. 5). Increases in the $\mathrm{Ni}-\mathrm{S}$ and $\mathrm{Mg}-\mathrm{S}$ correlation indexes from the oldest leaves to the youngest ones were observed for nearly each of the three plant replicates, (Fig. 5a, b). Furthemore, Ni and $\mathrm{S}$ concentrations in the epidermis were higher in the very young or mature leaves than in the very old ones (Fig. 4a, b). In addition, the epidermis position had no effects on these $\mathrm{Ni}$ and $\mathrm{S}$ concentrations, whatever the leaf age. A significant difference was observed between the young and mature leaves, rich in both $\mathrm{S}$ and $\mathrm{Ni}$, and the old and very old leaves, which were twice as poor in both $\mathrm{S}$ and Ni (Table S3). The exception was the young leaf of the P4 plant replicate for which both $\mathrm{Ni}$ and $\mathrm{S}$ concentrations were the lowest in both epidermis layers. A very significant spatial $\mathrm{Ni}-\mathrm{S}$ correlation can thus be observed in this peculiar young leaf (Figs. S5a and S5b). The $\mathrm{S}: \mathrm{Ni}$ mass ratio in the epidermis was fairly independent of leaf age, except for the young leaves where this was always slightly higher (Fig. S7a). Significant $(P<0.001)$ positive combined time-series correlations 
between $\mathrm{Ni}, \mathrm{S}$ and $\mathrm{Mg}$ concentrations occurred within the upper epidermis of the young and mature leaves (Table S4). The $\mathrm{Mg}: \mathrm{Ni}, \mathrm{Ca}: \mathrm{Ni}$ and $\mathrm{P}: \mathrm{Ni}$ mass ratios of both epidermis layers was lower in the oldest leaves than in the mature leaves, and slightly higher in young leaves than in the mature leaves (Fig. 6). Correlations between $\mathrm{Ni}$ and other element concentrations were also the most diverse and the greatest within the upper epidermis of the young leaves (Table S4), which were also characterized by the highest stomatal density and leaf transpiration flux (Fig. 3).

In the whole tissue series, the spatial distribution of $\mathrm{Ca}$ concentration in leaves was mostly opposite to $\mathrm{Ni}, \mathrm{S}$ or $\mathrm{Mg}$ concentrations, with parenchymas being richer than their epidermis in Ca (Fig. 4; Figs. S6 and S7). Consequently, almost no spatial $\mathrm{Ca}-\mathrm{Ni}, \mathrm{Ca}-\mathrm{S}$ and $\mathrm{Ca}-$ $\mathrm{Mg}$ correlations were observed within the tissue series. Indeed, negative $\mathrm{Ca}-\mathrm{Ni}$ and $\mathrm{Ca}-\mathrm{S}$ correlations were visible for two of the three young leaf replicates (Fig. 5 d). $\mathrm{Ni}$ and $\mathrm{Ca}$ concentrations in the two parenchymas were significantly $(P<0.001)$ positively correlated, except in the case of the young leaves. However, the $\mathrm{Ni}-\mathrm{Ca}$ correlation was less significant or did not exist for either of the epidermis (Tables S4, S5, S6 and S7).

Principal-component analysis showed the wide variations in element concentrations occurring between the three plant replicates. The most visible differences were between both epidermis layers and both parenchymas, upper and lower (Figs. S8a, S8c and S8e). This analysis also revealed a difference between, on the one hand, the young and mature leaves and, on the other hand the old and very old leaves (Figs. S8b, S8d and S8f). For the P4 and $\mathrm{P} 6$ plant replicates, the main contributions for the first axis were the leaf tissue $\mathrm{Ni}, \mathrm{S}$ and $\mathrm{Mg}$ mass concentrations (17.6-18.1, 17.2-25.3 and 27.5-29.2\%, respectively). In contrast, the key contributions for the second axis were always the leaf tissue $\mathrm{K}$ and $\mathrm{P}$ mass concentrations $(21.8-52.9$ and $15.6-29.7 \%$, respectively).

\section{Discussion}

Phenotypic-based variability of leaf or leaf-tissue $\mathrm{Ni}$ concentration

For the Ni-hyperaccumulator L. emarginata, variations in leaf or leaf-tissue Ni concentrations were always explained by a combination of individual plant and leaf age effects, with interactions between these two main factors. Variations in leaf transpiration flux, WUE, leaf moisture, leaf-tissue $\mathrm{S}, \mathrm{Mg}, \mathrm{Ca}, \mathrm{K}$ and $\mathrm{P}$ concentrations were also explained by a combination of individual plant and leaf age effects, except for the upper epidermis, the palissadic parenchyma $\mathrm{Mg}$ concentrations, and for the lower epidermis $\mathrm{K}$ concentrations. These wide phenotypic-based variations were attributed to the outcrossing (allogamous) fertilisation system of the $\mathrm{Ni}$-hyperaccu- mulator L. emarginata (formerly Peltaria emarginata) previously determined by Peer et al. (2006). Leptoplax emarginata is also biannual, with $2 \mathrm{n}=14$ chromosomes and a genome size (2C) of 1.8-2.0, about three times greater than most other metal hyperaccumulating plants such as $N$. caerulescens (formerly Thlaspi caerulescens), Noccaea fendleri (formerly Thlaspi montanum) or Arabidopsis halleri (Peer et al. 2003, 2006).

Underlying mechanisms of age-dependent leaf $\mathrm{Ni}$ accumulation

In this study, leaf $\mathrm{Ni}$ concentration values were $1.38-1.25 \mathrm{mg} \mathrm{Ni} \mathrm{g}^{-1}$ (young leaves), whereas for the same population of $L$. emarginata collected at seeding stage in the field (on Ni-rich ultramafic soils in Trigona, Pindus mountains, Greece), leaf Ni concentration was ten times greater (leaf $\mathrm{Ni}$ concentration of $13.6 \pm 0.1 \mathrm{mg} \mathrm{Ni} \mathrm{g}^{-1}$, Bani et al. 2009). These results highlight that the classical leaf-tissue $\mathrm{Ni}$ analysis carried out on a single leaf belonging to a single individual plant is open to question. There is a need for interpretation of leaf or leaf-tissue concentrations in the light of leaf traits as it has already been pointed out for Co hyperaccumulators (Lange et al. 2017b).

Our objectives were achieved through relevant methodologies, i.e. the use of rapid freezing and freezedrying of leaf samples before energy-dispersive spectrometry (EDS) analyses linked to SEM, in order to avoid elemental $\mathrm{Ni}$ (and nutrients) redistribution in leaf tissues (van der Ent et al. 2017). The hypothesis that Ni is transported along with the transpiration stream (Coinchelin et al. 2012) is supported by the facts that (1) $\mathrm{Ni}$ was predominantly located in the epidermis, Ni being seven times more concentrated in both epidermis layers than in their bulk neighbouring leaf counterparts and (2) the greatest $\mathrm{Ni}$ concentrations occurred in the highly transpiring young and thin leaves with the greatest stomatal densities. However, there is also evidence, as recently shown for $N$. caerulescens, that $\mathrm{Ni}$ is strongly redistributed from old to young leaves by phloem stream under the form of malate complexes (Deng et al. 2016).

These highly-transpiring young leaves, and the mature leaves, were also characterized by strong positive spatial or time-series $\mathrm{Ni}-\mathrm{S}$ correlations at the leaf-tissue scale. Moreover, principal-component analysis revealed an opposition between, on the one hand, both epidermis layers, which are rich in $\mathrm{Ni}, \mathrm{S}$ and $\mathrm{Mg}$, particularly those of the young and mature leaves, and, on the other hand, the two parenchymas, which are rich in $\mathrm{K}, \mathrm{P}$ and $\mathrm{Ca}$. The question arises as to $\mathrm{Ni}$ speciation in specific tissues of the leaves. Peer et al. (2006) observed that concentrations of $O$-acetyl-L-serine in shoots of 18 hyperaccumulating plants from Brassicacae family collected from natural sites, including two Greek L. emarginata populations, are strongly correlated with their ability to hyperaccumulate $\mathrm{Ni}$ in their shoots. Plants are highly capable of coupling photosynthesis to a reduction in 
sulfate, assimilation into cysteine, and further metabolism into methionine, glutathione, and many other compounds (Leustek et al. 2000; Leustek 2002), key sulfur ligands for metals (Küpper et al. 2004; Freeman et al. 2004, 2006; Haydon and Cobbett 2007; Mijovilovich et al. 2009; Richau et al. 2009). Such S assimilation is regulated during development, where the greatest activity of sulfur assimilation enzymes takes place at the growing points, i.e. the youngest leaves and the root tips (Leustek et al. 2000; Leustek 2002). Indeed, we observed that young leaves were richer in $\mathrm{S}$ than mature or old leaves, even without $\mathrm{Ni}$ in the substrate. The question arises as to whether Ni complexation occurs with sulfonate ligands. A negative answer can be formulated because ligands responsible for the $\mathrm{Ni}$ transfer within 4 month-old Ni-hyperaccumulator L. emarginata were citrate and malate (Montargès-Pelletier et al. 2008), rendering $\mathrm{Ni}$ much more mobile, whereas malate was found as the predominant ligand of leaf $\mathrm{Ni}$ (X-ray absorption spectroscopy). It was also shown that malate is involved in phloem re-translocation of $\mathrm{Ni}$ in hyperaccumulating Brassicaceae (Deng et al. 2016). Moreover, $\mathrm{CaSO}_{4}$ crystals were observed around the stomata on air-dried leaves (SEM-EDS observations and analyses, data not shown). This suggests that $\mathrm{Ni}$ is partly accumulated in leaf epidermis along with sulfate ions, also bearing in mind that $\mathrm{Ni}$ was already supplied in the form of $\mathrm{NiSO}_{4} 7 \mathrm{H}_{2} \mathrm{O}$. Moreover, the speciation of $\mathrm{Ni}$ in the xylem sap was proved to be mostly under the free ion in hyperaccumulating Alyssum species (Alves et al. 2011; Centofanti et al. 2013) and it was also shown that none of the chelating molecules (e.g. malate, citrate, nicotianamine) were at comparable concentrations to $\mathrm{Ni}$ in xylem sap. We suggest that sulfate, which is uploaded through the xylem with $\mathrm{Ni}$, forms the weak $\mathrm{Ni}\left(\mathrm{SO}_{4}\right)^{0}$ complex that is transported along the transpiration stream towards the leaf epidermis, although this remains to be demonstrated.

The age-dependent $\mathrm{S}: \mathrm{Ni}, \mathrm{Ca}: \mathrm{Ni}, \mathrm{P}: \mathrm{Ni}$ and $\mathrm{K}: \mathrm{Ni}$ mass ratios in the whole leaves or in the leaf tissues may be attributed to the relative phloem Ni mobility (Deng et al. 2016), as $\mathrm{Ca}, \mathrm{K}$ and $\mathrm{P}$ seem to be rather phloem-immobile compared to Ni. Unfortunately, $\mathrm{Ca}, \mathrm{Mg}, \mathrm{P}$ and $\mathrm{S}$ were not monitored in their study (Deng et al. 2016). The fact that $\mathrm{Mg}$ concentration in the epidermis tended to be higher in the very old leaves than in the young leaves (in contrast to $\mathrm{Ni}$ and $\mathrm{S}$ concentrations), would suggest a joint transport of $\mathrm{Ni}$ and $\mathrm{Mg}$ in the transpiration stream (xylem to stomata and epidermis) and possibly the role of sulfate ions at least as counter-ions to facilitate their mobility. However, phloem mobility of $\mathrm{Ni}$ would induce $\mathrm{Ni}$ redistribution in newer leaves, whereas $\mathrm{Mg}$ would remain phloem-immobile, thus further increasing the $\mathrm{Ni}$ concentrations in active transpiring young leaves. The re-mobilisation of $\mathrm{Ni}$ from mature to young leaves has certainly implications on the
$\mathrm{Ni}$ re-cycling through leaf litter decay, although $\mathrm{Ni}$ biogeochemical recycling in soil-hyperaccumulator systems has been shown to be extremely intense in the case of Alyssum murale (Echevarria 2018).

\section{Conclusion and perspectives}

The classical leaf-tissue $\mathrm{Ni}$ analyses, which are carried out on a single leaf belonging to a single individual hyperaccumulating plant, is open to question in the light of our results. The characterization of time-series leaves belonging to at least three plant replicates, as in this study, appeared to be particularly relevant as variations in leaf or leaf-tissue Ni concentrations were partly explained by individual plant effects. We attributed this individual effect to the allogamous character of the Nihyperaccumulator L. emarginata.

The accumulation of $\mathrm{Ni}$ appears to be mediated by both the transpiration stream and phloem redistribution towards physiologically active (with high-transpiration rates) young leaves. Long-distance Ni transport via the xylem is predominant in the Ni-hyperaccumulator $L$. emarginata, whereas a complementary redistribution via the phloem from old to young leaves should also occur, as observed for $N$. caerulescens. A strong correlation and co-occurrence of $\mathrm{S}$ and $\mathrm{Ni}$ suggests that there might be some processes that involve both elements. The combined use of radioactive or stable tracers of $\mathrm{Ni}, \mathrm{S}, \mathrm{Mg}$, $\mathrm{Ca}$ or of $\mathrm{H}_{2}^{18} \mathrm{O}$, would help to unravel further issues concerning the spatio-temporal dynamics of the elements from xylem to leaf tissues over short periods and to evaluate the role of phloem redistribution in element segregation. Moreover, synchrotron techniques could also (micro-EXAFS) help understand the different mechanisms involved after $\mathrm{Ni}$ is downloaded from the xylem and during its further redistribution through phloem flux, including the potential interactions with sulfate ions. Also, some unpublished results on the $\mathrm{Ni}$ hyperaccumulating Brassicaceae $A$. murale showed that leaf traits could vary (e.g. SLA) among individuals of the same population if they are grown on either ultramafic or non-ultramafic soils. Therefore, it would be necessary for a better understanding of the mechanisms of $\mathrm{Ni}$ homeostasis to conduct such a study on L. emarginata and other hyperaccumulating Brassicaceae by comparing leaf treats and leaf $\mathrm{Ni}$ accumulation in a gradient of $\mathrm{Ni}$ availability from non-ultramafic to ultramafic soils.

Acknowledgements Trust and financial support from the Université de Lorraine, ADEME and Lorraine Regional Council given to Dr. David Coinchelin for his PhD Grant were greatly appreciated. We thank Helen Selliez for improving the English. The authors deeply acknowledge their co-author, the late Dr. François Bartoli, for the many years shared in developing creative research together and for his valuable friendship. 


\section{References}

Agrawal B, Lakshmanan V, Kaushik S, Bais HP (2012) Natural variation among Arabidopsis accessions reveals malic acid as a key mediator of Nickel (Ni) tolerance. Planta 236:477-489

Alves S, Nabais C, Simões Gonçalves MDL, Correia dos Santos MM (2011) Nickel speciation in the xylem sap of the hyperaccumulator Alyssum serpyllifolium ssp. Lusitanicum growing on serpentine soils of northeast Portugal. J Plant Physiol 168:1715-1722

Baker AJM, Brooks RR (1989) Terrestrial higher plants which hyperaccumulate metallic elements - a review of their distribution, ecology and phytochemistry. Biorecovery 1:81-126

Bani A, Echevarria G, Mullai A, Reeves RD, Morel JL, Sulçe S (2009) Nickel hyperaccumulation by Brassicaceae in serpentine soils of Albania and Northwest Greece. Northeast Nat 16:385-404

Bani A, Echevarria G, Sulçe S, Morel JL (2015) Improving the agronomy of Alyssum murale for extensive phytomining: a fiveyear field study. Int J Phytoremediat 17:117-127

Boyd RS, Jaffré T (2009) Elemental concentrations of eleven new caledonian plant species from serpentine soils: elemental correlations and leaf-age effects. Northeast Nat 16:93-110

Boyd RS, Jaffré T, Odom JW (1999) Variation in nickel content in the nickel-hyperaccumulating shrub Psychotria douarrei $(\mathrm{Ru}-$ biaceae) from New Caledonia. Biotropica 31:403-410

Brooks RR, Lee J, Reeves RD, Jaffré T (1977) Detection of nickeliferous rocks by analysis of herbarium specimens of indicator plants. J Geochem Explor 7:49-57

Cecchi L, Gabbrielli R, Arnetoli M, Gonnelli C, Hasko A, Selvi F (2010) Evolutionary lineages of nickel hyperaccumulation and systematics in European Alysseae (Brassicaceae): evidence from nrDNA sequence data. Ann Bot 106:751-767

Centofanti T, Sayers Z, Cabello-Conejo M, Kidd P, Nishizawa N, Kakei Y, Davis A, Sicher R, Chaney R (2013) Xylem exudate composition and root-to-shoot nickel translocation in Alyssum species. Plant Soil 373:59-75

Chaney RL, Angle JS, Broadhurst CL, Peters CA, Tapppero RV, Sparks DL (2007) Improved understanding of hyperaccumulation yields commercial phytoextraction and phytomining technologies. J Environ Qual 36:1429-1443

Coinchelin D, Bartoli F, Robin C, Echevarria G (2012) Ecophysiology of nickel phytoaccumulation: a simplified biophysical approach. J Exp Bot 63:5815-5827

Cosio C, DeSantis L, Frey B, Diallo S, Keller C (2005) Distribution of cadmium in leaves of Thlaspi caerulescens. J Exp Bot $56: 765-775$

Deng THB, Tang YT, van der Ent A, Sterckeman T, Echevarria G, Morel JL, Qiu RL (2016) Nickel translocation via the phloem in the hyperaccumulator Noccaea caerulescens (Brassicaceae). Plant Soil 404:35-45

Echevarria G (2018) Genesis and behaviour of ultramafic soils and consequences for nickel biogeochemistry. In: van der Ent A, Echevarria G, Baker AJM, Morel JL (eds) Agromining: farming for metals. Extracting unconventional resources using plants. Mineral Resources Series, Springer International Publishing AG, Cham, Switzerland, pp 135-156

Ernst WHO, Krauss GJ, Verkleij JOC, Wesenberg D (2008) Interaction of heavy metals with the sulfur metabolism in angiosperms from an ecological point of view. Plant Cell Environ $31: 123-143$

Estrade N, Cloquet C, Echevarria G, Sterckeman T, Deng THB, Tang YT, Morel JL (2015) Weathering and vegetation controls on nickel isotope fractionation in surface ultramafic environments (Albania). Earth Planet Sci Lett 423:24-25

Fernando DR, Mizuno T, Woodrow IE, Baker AJM, Collins RN (2010) Characterization of foliar manganese (Mn) in $\mathrm{Mn}$ hyperaccumulators using X-ray absorption spectroscopy. New Phytol 188:1014-1027
Food and Agriculture Organization of the United Nations (FAO) (2001) Lecture notes on the major soils of the world. In: Driessen P, Deckers J, Spaargaren O, Nachtergaele F (eds) World soil resources report, no. 94. FAO, Rome

Freeman JL, Persans MW, Nieman K, Albrecht C, Peer W, Pickering IJ, Salt D (2004) Increased glutathione biosynthesis plays a role in nickel tolerance in Thlaspi nickel hyperaccumulators. Plant Cell 16:2176-2191

Freeman JL, Zhang LH, Marcus MA, Fakra S, McGrath SP, Pilon-Smits AH (2006) Spatial imaging, speciation, and quantification of selenium in the hyperaccumulator plants Astragalus bisulcatus and Stanleya pinnata. Plant Physiol 142:124-134

Haydon MJ, Cobbett CS (2007) Transporters of ligands for essential metal ions in plants. New Phytol 174:499-506

Jaffré T, Schmid M (1974) Accumulation du nickel par une Rubiacée de Nouvelle-Calédonie, Psychotria douarrei (G. Beauvisage) Däniker. CR Acad Sci D Nat 278:1727-1730

Kachenko AG, Siegele R, Bhatia NP, Singh B, Ionescu M (2008a) Evaluation of specimen preparation techniques for micro-PIXE localisation of elements in hyperaccumulating plants. Nucl Inst Methods Phys Res B 266:1598-1604

Kachenko AG, Singh B, Bhatia NP, Siegele R (2008b) Quantitative elemental localisation in leaves and stems of nickel hyperaccumulating shrub Hybanthus floribundus subsp. floribundus using micro-PIXE spectroscopy. Nucl Inst Methods Phys Res B 266:667-676

Koopmans GF, Römkens PFAM, Song J, Temminghoff EJM, Japenga J (2007) Predicting the phytoextration duration to remediate heavy metals contaminated soils. Wat Air Soil Poll 181:355-371

Krämer U (2010) Metal hyperaccumulation in plants. Ann Rev Plant Biol 61:517-534

Krämer U, Pickering IJ, Prince RC, Raskin I, Salt DE (2000) Subcellular localization and speciation of nickel in hyperaccumulator and non-accumulator Thlaspi species. Plant Physiol 122:1343-1353

Küpper H, Lombi E, Zhao F-J, Wieshammer G, McGrath SP (2001) Cellular compartimentation of nickel in the hyperaccumulators Alyssum lesbiacum, Alyssum bertolonii and Thlaspi goesingense. J Exp Bot 52:2291-2300

Küpper H, Mijovilovich A, Meyer-Klaucke W, Kroneck MH (2004) Tissue- and age-dependent differences in the complexation of cadmium and zinc in the cadmium/zinc hyperaccumulator Thlaspi caerulescens (Ganges ecotype) revealed by X-Ray absorption spectrometry. Plant Physiol 134:748-757

Lange B, van der Ent A, Baker AJM, Mahy G, Malaisse F, Meerts P, Echevarria G, Pourré O, Verbruggen N, Faucon MP (2017a) Copper and cobalt accumulation in plants: a critical assessment of the current status of knowledge. New Phytol 213:537-551

Lange B, Faucon MP, Delhaye G, Hamiti N, Meerts P (2017b) Functional traits of a facultative metallophyte from tropical Africa: population variation and plasticity in response to cobalt. Environ Exp Bot 136:1-8

Le Thiec D, Rose C, Garrec JP, Laffray D, Louguet P, Galaup S, Loosveldt P (1994) Alteration of element subjected to ozone fumigation and (or) water stress: X-ray microanalysis study. Can J Bot 72:86-92

Leustek T (2002) Sulfate metabolism. The Arabidopsis book 1. https://doi.org/10.1199/tab.0017

Leustek T, Martin MN, Bick J-A, Davies JP (2000) Pathways and regulation of sulfur metabolism revealed through molecular and genetic studies. Ann Rev Plant Phys Plant Mol Biol 51:141-165

Li Y-M, Chaney RL, Brewer E, Roseberg R, Angle JS, Baker A, Reeves R, Nelkin J (2003) Development of a technology for commercial phytoextraction of nickel: economic and technical considerations. Plant Soil 249:107-115

McGrath SP, Zhao FJ, Lombi E (2002) Phytoremediation of metals, metalloids and radionuclides. Adv Agron 75:1-56

McNear DH, Chaney RL, Sparks DL (2010) The hyperaccumulator Allyssum murale uses complexation with nitrogen and oxygen donor ligands for $\mathrm{Ni}$ transport and storage. Phytochemistry $71: 188-200$ 
Mesjasz-Przybylowicz J, Przybylowicz WJ (2011) PIXE and metal hyperaccumulation: from soil to plants and insects. X-Ray Spectrom 40:181-185

Mesjasz-Przybylowicz J, Przybylowicz WJ, Pineda CA (2001) Nuclear microprobe studies of elemental distribution in apical leaves of the Ni hyperaccumulator Berkheya coddii. S Afr J Sci 97:591-593

Mijovilovich A, Leitenmaier B, Meyer-Klaucke W, Kroneck MH, Götz B, Küpper H (2009) Complexation and toxicity of copper in higher plants. II. Different mechanisms for copper versus cadmium detoxification in the copper-sensitive cadmium/zinc hyperaccumulator Thlaspi caerulescens (Ganges ecotype). Plant Physiol 151:715-731

Montargès-Pelletier E, Chardot V, Echevarria G, Michot LJ, Bauer A, Morel JL (2008) Identification of nickel chelators in three hyperaccumulating plants: an X-ray spectroscopic study. Phytochemistry 69:1695-1709

Nick LJ, Chambers MF (1995) Farming for metals? Mining Environ Manag 3:15-18

Peer WA, Mahmoudian M, Lahner B, Reeves RD, Murphy AS, Salt DE (2003) Identifying model metal hyperaccumulation plants: germplasm analysis of 20 Brassicaceae accessions from a wide geographical area. New Phytol 159:421-430

Peer WA, Mahmoudian M, Freeman JL, Lahner B, Richards EL, Reeves RD, Murphy AS, Salt DE (2006) Assessment of plants from the Brassicaceae family as genetic models for the study of nickel and zinc hyperaccumulation. New Phytol 172:248-260

Perronnet K, Schwartz C, Morel JL (2003) Distribution of cadmium and zinc in the hyperaccumulator Thlaspi caerulescens grown on multicontaminated soil. Plant Soil 249:19-25

Reeves RD, Brooks RR, Press JR (1980) Nickel accumulation by species of Peltaria Jacq. (Cruciferae). Taxonomy 29:629-633

Richau KH, Schat H (2009) Intraspecific variation of nickel and zinc accumulation and tolerance in the hyperaccumulator $T h$ laspi caerulescens. Plant Soil 314:253-262

Richau KH, Kozhevnikova AD, Seregin IV, Vooijs R, Koevoets PLM, Smith JAC, Ivanov VB, Schat H (2009) Chelation by histidine inhibits the vacuolar sequestration of nickel in roots of the hyperaccumulator Thlaspi caerulescens. New Phytol $183: 106-116$
Robinson BH, Fernández JE, Madejón P, Marañón T, Murillo JM, Green S, Clothier B (2003a) Phytoextraction: an assessment of biogeochemical and economic viability. Plant Soil 249:117-125

Robinson BH, Lombi E, Zhao FJ, McGrath SP (2003b) Uptake and distribution of nickel and other metals in the hyperaccumulator Berkheya coddii. New Phytol 158:279-285

Tang YT, Deng THB, Wu QH, Qiu RL, Wei ZB, Guo XF, Wu QT, Lei M, Chen TB, Echevarria G, Sterckeman T, Simonnot MO, Morel JL (2012) Designing cropping systems adapted to metal contaminated sites: a review. Pedosphere 22:470-488

Tian SK, Lu LL, Yang XE, Labavitch JM, Huang YY, Brown P (2009) Stem and leaf sequestration of zinc at the cellular level in the hyperaccumulator Sedum alfredii. New Phytol 182:116-126

van der Ent A, Baker AJM, Reeves RD, Chaney RL, Anderson CWN, Meech JA, Erskine PD, Simonnot M-O, Vaughan J, Morel JL, Echevarria G, Fogliani B, Rongliang Q, Mulligan DR (2015) Agromining: farming for metals in the future? Environ Sci Technol 49:4773-4780

van der Ent A, Callahan DL, Noller BN, Mesjasz-Przybylowicz J, Przybylowicz WJ, Barnabas A, Harris HH (2017) Nickel biopathways in tropical nickel hyperaccumulating trees from Sabah (Malaysia). Sci Rep 7:41861

Verbruggen N, Hermans C, Schat H (2009) Molecular mechanisms of metal hyperaccumulation in plants. New Phytol 181:759-776

Vogel-Mikuš K, Regvar M, Mesjasz-Przybyłowicz J, Przybyłowicz W, Simčič J, Pelicon P, Budnar M (2008) Spatial distribution of cadmium in leaves of metal hyperaccumulating Thlaspi praecox using micro-PIXE. New Phytol 179:712-721

Xu X, Shi J, Chen Y, Chen X, Wang H, Perera A (2006) Distribution and mobility of manganese in the hyperaccumulator plant Phytolacca acinosa Roxb. (Phytolaccaceaae). Plant Soil 285:323-331 